\title{
ESSAYS
}

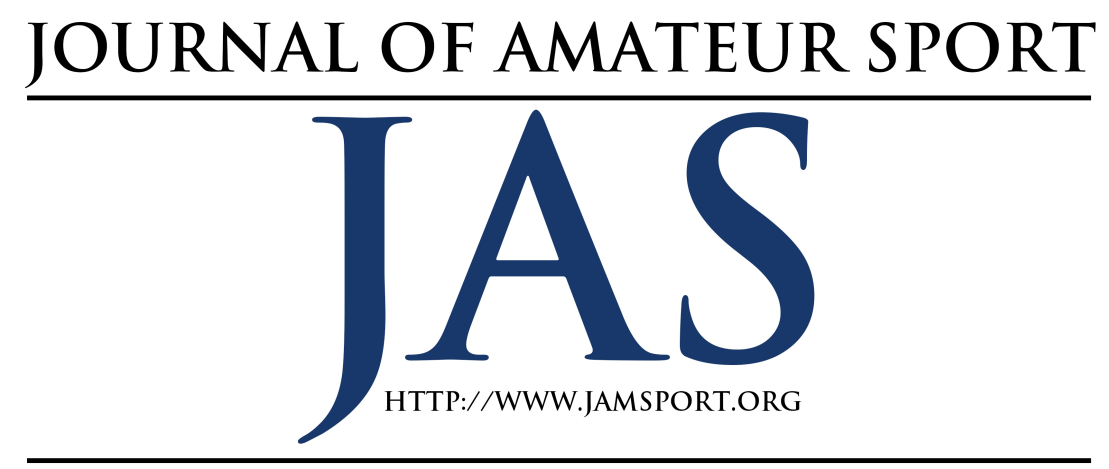

\section{Educated Ignorance: What Faculty Don't Know and Why Faculty Can't Lead Intercollegiate Athletics Reform}

\author{
Travis Feezell \\ University of the Ozarks
}

\begin{abstract}
Contemporary writings on the tension of athletics and academics in American higher education have often focused on the incompatibility of sporting endeavors and institutional missions. In particular, scholarship has stressed the ills of a financially directed collegiate sports machine at odds with the general educational aims of colleges and universities. However, this essay attempts to examine the historical and structural traditions of higher education, particularly those surrounding faculty, as a means of evaluating the tension. Moreover, the essay suggests a radical re-evaluation of those structures as a means to ameliorate the ongoing scandal in our institutions.
\end{abstract}

$\mathrm{I}$ $\mathrm{n}$ a recent piece from the Charlotte Observer (DeCock, 2013), the columnist expressed dismay at the silence of faculty in regards to the recent academic scandal at the University of North Carolina. As one might expect, he emphasized the intentional fraudulent actions of one faculty member as the locus for scandal, yet his comments in large part were directed at an alarming lack of reaction by faculty to this situation that had attacked the upstanding reputation of a flagship public institution. Faculty - as he seemed to be implying are indeed responsible for the integrity of the university and must give voice and action when the institution is assailed by unethical and unseemly actions, particularly those actions that spring from intercollegiate athletics. Why shouldn't faculty stand up at this crucial moment? Why wouldn't they? 
As the scandal continued to unfold with particular claims of "no-show" classes and the institutional enrollment of athletes with severe academic deficiencies, faculty again seemed unusually inactive. A new chancellor of the university - the former chancellor had left in the wake of these problems acknowledged the institution's responsibility in the scandal but also questioned the data and conclusions of one advisor's research into the reading abilities of many student-athletes. Faculty responded with positive commentary to the chancellor's words, yet the language of faculty seemed to suggest an abdication of leadership in any response to the scandal to institutional administration (Stancil, 2014). Why this abdication? Why wouldn't faculty lead the way in any reform, particularly if faculty are at the heart of an institution?

This paper attempts to answer these questions in a most direct and comprehensive way. ${ }^{1}$ The aforementioned columnist's lament is an oft heard public "cry in the wilderness" for faculty action in reforming college

\footnotetext{
1 Throughout this paper I will provide commentary on a number of issues including faculty participation, faculty governance, and athletics reform in American higher education. The nature of this paper is to articulate a synthesis of preceding writings in these areas and provide both a taxonomy of faculty attitudes as well as a concluding statement on the ineffectiveness of faculty reform efforts. Thus at times I will note specific references where necessary and attempt to identify particularly effective commentary. I also would direct the reader to the list of references at the conclusion of the paper, which have informed the writer's conclusions and opinions.
}

athletics; many have expressed that leadership in these reform efforts must come not from the wolves guarding the hen house, but must instead emanate from the ethical and moral center of an institution- its professoriate. Yet I want to suggest that these calls for faculty leadership are misdirected; faculty are influenced in their opinions and actions toward intercollegiate athletics by a number of elements including historical and systemic traditions in higher education. This "educated ignorance" an education of faculty into certain norms and traditions of American higher education - prevents faculty from providing meaningful and sustainable reform efforts in regards to athletics. The question then is not whether faculty should lead during times of scandal but why faculty cannot and will not provide leadership in intercollegiate athletics issues in the future.

Faculty, many experts aver, are indeed the heart, the soul, and particularly the mind of higher education. Former Harvard University president Derek Bok (2003) looked to faculty as the gatekeepers on campus noting the imperative of faculty to defend academic standards and institutional values; this, he argued, protects the quality and integrity of all academic work. Such a characterization calls on faculty to actively participate in the life and direction of the campus. And though many would argue that the mission of an 
institution is multi-faceted, faculty members do indeed have central roles in the governance of the university, particularly in two forms.

Faculty most obviously participate in university-wide governance in the form of academic senates or other groups that lend opinion to the administration on prominent university issues. It would seem that faculty do indeed have influence in the general administrative affairs of institutions, though this may be limited only to an advisory capacity heard through a singular faculty "voice." Furthermore, this voice is best heard on topics of general university administration when faculty members have more knowledge than trustees, administrators, or others in traditional decision-making roles. Yet faculty also act within the academic units of the institution (i.e., departments, divisions, schools, colleges) to manage the curricular business of the institution, controlling in some sense the very heart of the academic activity of any college or university. Without doubt, a departmental curricular decision or some other similar choice can have far reaching effects upon the overall direction of an institution.

However, faculty engagement with intercollegiate athletics, and in particular faculty governance and oversight of athletics, seems a much more vexing problem. One need only witness the most recent scandals at Penn State University and the University of North
Carolina where faculty seemed to be notably absent. In the UNC case, a rogue faculty member was seemingly one of the primary causes of the problem. James Duderstadt (2000), the former president of the University of Michigan, expressed that faculty take an interest in athletics because of the perceived educational benefit of the activity, yet shy away from "true control" because of time constraints, lack of formal knowledge and an unwillingness to accept responsibility. Consequently, faculty are left to lament the problems of intercollegiate athletics, sometimes in a most vocal way, but rarely do they engage in a meaningful way so as to govern athletics in concert with the institutional mission. Such was the recent outcry of faculty at the University of Maryland when university leaders failed to consult faculty on the impending move to a new athletics conference.

But perhaps this outcry should not be a surprise. While faculty may have some influence on the direction of an institution, it is with increasing frequency that leaders of institutions - perhaps guided most by the lure of increased revenue and visibility - marginalize faculty when decisions concerning athletics are made. Leaders argue in some cases that athletics is outside the scope of academic scrutiny. By athletics not being "curricular" in nature, it does not fall within the concerns of faculty governance. Faculty are rarely consulted 
on matters of residence hall living or parking or dining hall food. Why should athletics be any different?

Moreover, in recent research, it has been suggested that faculty members at the largest research institutions, particularly those with highly successful and visible athletics programs, have significantly less positive attitudes towards intercollegiate athletics than small-school faculty members (Feezell, 2005; Feezell, 2013). In this negative assessment, faculty members view athletics as an extracurricular activity largely disconnected from the central academic and research mission of the institution. At the most basic level, athletics are not integrated into the educational fabric of the institution and faculty members do not engage with athletics in meaningful and consistent ways. More specifically, faculty governance as a means of engagement is sporadic and reactive to perceived ills in athletics as opposed to a more general faculty directive of athletics integration found at smaller schools.

I argue that faculty must have an invested interest in athletics. The very nature of the enterprise - its overflowing stadia, marginalized student-athletes, and enormous resource requirements require more faculty engagement with athletics. How can we not be called to action when the athletics enterprise may dictate our relationships with other institutions through conference affiliation? How can we not be invested when at some schools leaders have called for the cancellation of evening classes because of a midweek football game? Wasn't football once just a Saturday affair? How can we not want our voice to be heard when athletics is more often the "front porch" in admissions recruitment efforts and academic programs are pushed into the background?

The voice of faculty is often found in the form of limited faculty governance associated with athletics. More specifically, faculty members generally have two means of engagement. First, most institutions have formed a faculty oversight group for athletics, yet the purpose of these groups is often inconsistent. Some may set policy, others may be more advisory in nature, while a few may even be quite powerless and are formed as a mollifying action by the president of the institution on behalf of a vocal faculty. Second, the National Collegiate Athletic Association (NCAA) has mandated that all institutions name a Faculty Athletics Representative (FAR) that will be active in institutional athletics affairs. But similar to the oversight group, the FAR's role is ill defined.

Furthermore, there are some who view this position with a suspicious eye. As opposed to serving as the "watchdog" of the faculty, this FAR instead panders to the corporate ethos of big-time athletics, accepting de facto bribes in the form of free tickets to games, parking passes, 
lavish meals and logoed athletics apparel. Other faculty are not immune to similar criticism. On the rare occasion that faculty members do engage with athletics through the classroom or some other educational setting, the criticism of such engagement is that these professors are acquiescent to an overly indulged and disconnected athletics department that has no specific connection to the academic purpose of the institution.

But the undertone here is not that faculty are critiquing colleagues but instead finding extreme fault with the entire intercollegiate athletics enterprise. ${ }^{2}$ Such criticism of athletics generally falls into four categories, often somewhat intertwined in their expression. Most criticism begins with a base founded in the aberrant direction of athletics, that these mere games have nothing to do with the central mission of the institution. Faculty lament that athletics has little in common with the life of the mind and that in most cases physical activity of this magnitude and emphasis distracts students, both fans AND participants, from the core of academic rigor at the heart of an institution. Many note the isolation of student-athletes with

2 There are a number of studies and commentary included in the reference section that can provide a comprehensive analysis of these issues. I would particularly point out the work of Sperber (1990; 2000), Gerdy (2006), Beyer and Hannah (2000), and Sack (2009) among the many. In addition, James Frey's discussion of organizational deviance and college athletics (1994) provides an excellent theoretical framework for understanding the disconnect between the academy and athletics. special services in counseling, nutrition, academic tutoring, and the like that seem to have more to do with athletic success than academic growth.

A second source of criticism is the seeming disparity in financial and personnel resources between the athletic and academic realms. Exorbitant salaries of superstar coaches, budget expenditures for recruiting, and monolithic athletic structures for the sole use of "gladiatorial" games are at odds with the meager pay of an English professor or the limited research resources of a life scientist. The sharpness of the criticism and the vitriol of faculty grows further when athletics spending draws from other areas of the institution; in times of tightly controlled resources, faculty cannot stomach misuse of funds, particularly in an area disconnected from the academic side of things and one which has little payback to the overall institutional good.

A third source of criticism from faculty directs its focus at the overall student composition of the institution. That is, there is often criticism about the possible notion that athletics attracts and enrolls students who do not "fit" the institution in any way other than with their desired physical gifts. A place in the student body given to a behemoth that can play on the offensive line or dunk a basketball but with poor writing skills is a place not given to someone with better 
academic tools that would enhance the classroom or the research lab.

Finally, faculty criticism laments the overall magnitude of the athletics enterprise. Stadiums that seat 100,000 screaming fans, television contracts that pay hundreds of thousands of dollars with games in far-flung places on weekday nights no less, coaching and support staffs that have ratios of student oversight at the 1:1 level ... these things and more lead faculty to wonder what the priorities of an institution may be. Or perhaps better yet, lead faculty to wonder why others would prioritize the athletic over the academic.

It seems that in this state of affairs faculty are left in an awkward role, that of a lapdog or uninterested observer; regardless, faculty for the most part are disengaged from intercollegiate athletics. This divide from athletics has most often been observed from the vantage point of faculty members with the microscope upon the athletics department. Athletics proponents have responded in a variety of ways but have most often defended the place of intercollegiate athletics as contributing to a more holistic notion of education of students, that is, an education beyond books and specific knowledge that includes something more about "life lessons" and "character building." Moreover, athletics has defended its position as contributing to the branding and identity of the institution and, in the best cases, as contributing to the overall financial health of the university. With such marked positions, how are we to view the athletic-academic divide? The athletics culture wants nothing to do with the academic and the academic group thinks it should stay that way. The tenets of the debate are oft repeated and the arguments seem to lend little towards exploration of the continuing conflict. Scandals (re)appear at a consistent rate, faculty complain with the same language, and time moves on.

However, let me suggest that circumstance rather than choice is at the root of the divide, and by extension suggest an approach to the problem, one a historical examination of forces and the other an assessment of contributing faculty attitudes inherent in higher education, that might illuminate faculty disengagement and the athletic-academic divide. Let me further suggest that the investigation of the divide thus far has been to turn the microscope on athletics and in doing so define the problems in those activities vis-à-vis the faculty position. More distinctly, examinations of the issues in athletics most often have been tinged with the frustrations of faculty members; in essence, the examination has become both a description of the ills of athletics AND a definitional exercise about what faculty value most about their position as gatekeepers of the institutional mission. However, I might suggest that in light of 
recent scandals, faculty must turn the investigation inwards. That is, perhaps it is time to examine the state of faculty and both the personal and structural impediments to meaningful engagement with intercollegiate athletics.

\section{Higher Education and the Athletic- Academic Divide: Systemic Impediment}

I would first argue that the contemporary place of faculty in relation to athletics is not accidental in any way. Rather, it is an outgrowth of historical movements in higher education that has contributed to our current state of affairs. ${ }^{3}$ First, the influence of the British, German, and colonial models of higher education contribute to the athleticacademic divide from an early state. Presidential control of institutional identity during the 1800's and the desire to attract students, particularly through the development and promotion of athletics teams, certainly influences contemporary intercollegiate athletics programs. Furthermore, the development of the research university and the quest for specific knowledge took faculty members further away from student interests and promoted a facultycentered, rather than student-centered, approach to education. This movement

\footnotetext{
3 Ronald Smith's work on the development of intercollegiate athletics $(1988 ; 2011)$ provides a brilliant overview of the ongoing tensions between the academy and athletics. See especially pages 187-97 (2011) which discusses faculty reform efforts.
}

toward the fractionalization of the twentieth-century university led to a distancing of faculty from athletics; academic specialization diminished the connection between faculty and athletics and pushed athletics to the fringes of the academic enterprise, an isolation and independence which in fact contributed to the growth of athletics over the last few decades.

Moreover, an athletics department left to its own development over the past decades by faculty has created independent mechanisms of protection. In the early years of the 20th century, athletics departments were housed within physical education programs and coaches had teaching duties that integrated them within the overall faculty activity of the institution. Yet as interest grew in athletics, as demands increased, and as happened with faculty in general, specialization required that coaches become singularly attached to the sports they managed, and by extension distanced themselves far from the academic enterprise. Clearly, access to newly found financial resources contributed as well to this distance. What had been institutional subsidy for modest athletics activities mutated into a grandiose self-funded athletic spectacle over the course of time.

I then would suggest the following five contemporary features of higher education and faculty as inhibiting factors in faculty engagement with athletics. 


\section{Feature \#1 - The Fragmentation of the Contemporary University}

Contemporary universities are highly complex organizations with loose associations between the varied departments. It would seem that faculty view departments and academic divisions/colleges as personal turf highly deserving of limited institutional resources and thus requiring enormous amounts of attention. Moreover, the fragmentation of the contemporary university often disassociates faculty members from each other and from the overall faculty governance of the institution. As President Duderstadt (2000) noted further in his critique of contemporary higher education, faculty are more interested in personal goals and only become connected to universitywide goals when the two intersect. And in the worst form, faculty members are separated from students as well. The urban myth of the professor wanting nothing to do with undergraduate education and everything to do with research is indeed disheartening. Faculty should have a role to play in the governance of athletics just as they have a role in institutional governance, but too often deny that responsibility in the name of research or some other personal, research, or departmental endeavor.

\section{Feature \#2 - Graduate School Indoctrination}

Many faculty members are products of an "academic subculture" and continue to inhabit and perpetuate this subculture through research, teaching, and graduate mentoring activities. ${ }^{4}$ In this last area, notions of loyalty to the academic discipline rather than the institution are prioritized and the importance of research is inculcated as professors train the "next generation." And what are graduate students learning? Among other things they are learning to distance themselves from the undergraduate affairs, from institutional demands, and ultimately from athletics engagement.

\section{Feature \#3-Tenure}

Tenure and its relation to faculty governance may be at odds with the very "public purpose" and "public accountability" of universities and colleges; faculty have an autonomy that may skew decision-making in the direction of personal interests rather than those that involve the public good. Moreover, this conflict of the personal versus the public is self-imposed. The heightened personal and professional importance of research in the tenuretrack job has inclined many to lessen their roles in all faculty governance areas. One faculty member describes it like this: Further, the emphasis on research as a main demand for all full-time

\footnotetext{
${ }^{4}$ Sperber (2000) has an excellent discussion of these subcultures; see especially pages 3-11.
} 
faculty - overtaking all service activities - forced us into a separation of service elements from faculty work and an outsourcing of them to a growing middle management sector in the university. Thus faculty administrative jobs like advising, teaching freshmen, running the elementary or basic skills programs, attending to pedagogy - have become the province of non-faculty, and faculty (growing a little lazy as well as over specialized?) have been willing to acquiesce in such outsourcing (Burgan, 1998, p. 20).

Another faculty member notes:

Faculty themselves have played a role in developing a reward system in a narrowly defined discipline but not loyalty and commitment to the institution and to higher education in general. ... shared governance cannot succeed if faculty are not willing to be actively involved in efforts to identify and advance the best interests of the entire institution, and not just their own discipline (Gerber, 1997, p. 16). This last observation - that of faculty interested only in personal advancement and matters of academic discipline - may well be the starting point for a disengaged faculty. The allegiance from the beginning of an academic career is to self-preservation and to scholarly passions. Why would faculty - rather, why should faculty? - care to partake in the governance of something as frivolous as ballgames on a field?

\section{Feature \#4 - "Instructors"}

\section{Without a Home}

The growing ranks of part-time and adjunct faculty members certainly pose a threat to the efficacy of faculty governance in general and the willing engagement of faculty in curricular and institutional affairs. In regards to engagement with athletics, part-time and adjunct instructors may see studentathletes in the classroom, but would have little interest in connecting their extracurricular activities to a greater institutional good. Moreover, having an interest in the governance of athletics suggests a connection to the institution beyond the meager adjunct paycheck. Simply put, as the number of itinerant instructors grows - and I would suggest that it is likely to do so given the current economic state of higher education - so grows the deepening disconnect between instructor and the "community" of an institution.

\section{Feature \#5 - The Marketing of Higher Education}

Higher education once proclaimed a proud purpose to create great citizens that would contribute to the public good. Though the proclamation is sometimes heard today, many would argue that for a variety of reasons the public benefit has shifted to the private and the personal. Higher education is now narrowly 
directed at the individual not as some civic-minded training exercise, but as a means to a better job and a way to service personal desires. To its external clients, higher education is now "sold" to the highest bidder in some marketed and packaged form. ${ }^{5}$ The result is a bureaucratic and unwieldy institution whose governance tends towards a more corporate and hierarchical model that excludes the faculty voice. Intercollegiate athletics serves as one of many marketing strategies for the institution; moreover, athletics has served this purpose for some time. Yet such a lucrative marketing tactic with literally millions of dollars at stake seems to demand the attention of a CFO rather than a Dean or Provost or lowly faculty member.

Additionally, I would argue that some schools - primarily smaller and private schools outside of the NCAA Division I ranks - finance themselves through enrollments rather than endowments and thus utilize athletics as a primary institutional funding strategy. In this, baseball teams exceed seventy players while football teams can reach above one hundred or more. When budgets and institutional health are tantamount, clearly athletics needs may trump faculty governance.

\section{The Contemporary Reaction: Who Are We?}

\footnotetext{
${ }^{5}$ See especially Derek Bok's (2003) work in this area among many.
}

How shall faculty overcome these features, this history, and this culture? Are faculty really willing and able to engage with athletics? Are faculty members actually interested in pursuing a more powerful voice in the governance of athletics? Certainly there are visible groups of faculty, notably the Drake Group and the Coalition On Intercollegiate Athletics (COIA), working at the governance of intercollegiate athletics. I might argue that COIA as a coalition of university faculty senates from around the country may indeed have impact upon the current state of things. In both mindful and strategic ways, COIA has chosen to work with the NCAA on a variety of issues hoping to have some influence on the macropicture of rules and policies that would affect individual universities.

Yet I am concerned that in the end COIA and other similar groups now and in the future may be ineffective, not because of a commendable raison d'etre and members' valiant efforts, but instead because of the nature of NCAA governance. NCAA policy at all levels is guided by those with the most vested interest in athletics programs. While publicly the NCAA will often describe athletics governance as being engineered by institutional CEO's, the real governance of athletics is formed and directed by athletics directors and conference commissioners. Before policy will reach the ears of any kind of 
presidential oversight, it has been carefully considered and crafted by athletics personnel to most often meet the needs of athletics constituents.

I also believe that faculty are not yet equipped to engage successfully with athletics, most often because of the systemic issues mentioned previously, but also because of a general lack of foundational preparation to meaningfully do so. Even when called to act, faculty may be indoctrinated to do otherwise or in some cases paralyzed to inaction by seeming powerlessness in the face of the contemporary athletic monolith.

In the late summer of 2010 as the academic scandal surrounding ghost classes at the University of North Carolina was unfolding, John Drescher, editor of the Raleigh News and Observer, wrote an intriguing op-ed piece which suggested that faculty needed to serve as the "conscience" to a university with bigtime athletics. Mr. Drescher's comments, particularly the questions he suggested faculty ask of the university chancellor, were spot-on and delightfully comprehensive in terms of faculty getting to the heart of Division I athletics. However, I found his finger pointing to be more an exercise in scapegoating. His suggestion that faculty could and should have prevented these scandals was woefully inadequate. Indeed, perhaps he should have been asking what prevented faculty from serving in the capacity he expected of them.
Faculty, I believe, generally fall into four categories in relation to their attitudes towards athletics ... "I Don't Care", "I Don't Know", “I Don’t Know How", and "Why Bother". A brief description of each state follows:

"I Do Not Care": The

contemporary university is indeed a "multiversity" with a great diversity of departments and aims. Many faculty frankly don't care about athletics and instead their focus is upon their research and their discipline The sphere of engagement for most faculty only extends to the bounds of their own department. Issues of institutional import only reach them when it directly affects that sphere. Should they care about an athletics department that has broader institutional influence? Of course! Do they? Of course not. The pursuit of tenure and the general business of departmental or divisional affairs consume energy and attention. Perhaps here the notion of the institutional good must be inculcated into what is valued and what is rewarded.

"I Do Not Know": Lawrence, Ott, and Hendricks from the University of Michigan in association with the Knight Commission undertook a study of faculty in 2007 which suggested many faculty "don't know about and are disconnected from issues around college sports." Anecdotally, I recall a specific exchange with a faculty member at a large research university in the Southeastern Conference who insisted that all Division 
I athletics programs make money. I had to point him to research, which suggested that only a handful of athletics programs make money, $10-20$ at most by most accounts. In this and other conversations I continue to have with faculty colleagues, I am struck by the stock (mis)understanding of contemporary college athletics that only sees various stadia full of inspired students cheering on the home team. And who can argue with that as long as it doesn't really interfere with what the faculty member is doing in her own department?

Knowledge must be the pillar of meaningful engagement with athletics and in this faculty are woefully unprepared. Of course there are faculty who study the place of sport in society and there has been a proliferation of sport-themed majors and programs in the last two decades within our colleges and universities. But the dreadful fact is that a strong majority of faculty are "educated" about college sport through a veil of ignorance. The atmosphere of ESPNification that envelops our understanding of college sports somehow suggests that money is just around the corner and all things good come of these college games. Scandal in college sports is really just the product of miscreants and outliers at least three standard deviations from the norm that can be fired from employment or dismissed. It's really just that simple, isn't it? For faculty to meaningfully engage they must know more. And in some cases, they must demand access to that information.

"I Do Not Know How": Of course there are faculty "in the know" and who do care deeply about this. As mentioned previously, there are a number of faculty groups and individual scholars that address some of these issues. But in addition to the historical tradition of faculty losing oversight of student athletic endeavors, particularly as those endeavors became more about institutional identity and enhanced financial leveraging, there seem to be few legitimate avenues for faculty to pursue substantive engagement with college athletics. One recent research study (Nichols et al, 2011) examined faculty governance bodies at a variety of institutions and found them lacking. In essence, the study suggested that only a "minority" of these bodies "exercised direct oversight in important academic matters, related to student-athletes, such as admissions, scholarships, advising, and integrity of majors and courses." (p. 119). Moreover, the actions listed previously were often left to either the FAR - a single individual representing the entire will of the faculty? - or some subcommittee of the campus governance structure. And still more curious, the research indicates that this subcommittee does not always include a faculty member. On the one hand, perhaps the faculty just don't care (see above), but perhaps it is more the case that faculty 
have not yet figured out an effective way to engage with athletics.

"Why Bother?": This new category of faculty attitude has been developed only lately and it may be more useful to see it as a more nuanced version of "I don't know how." In this, faculty are indeed acutely aware of the problems and issues surrounding athletics. In fact, these faculty may continually rail against the problems and author white papers and call attention to the many issues that arise. Clearly they educate colleagues on the problems. But in the end, there is little substantive change they engender. Perhaps it is because - as the Knight Commission Report suggested in 2007 presidents and chancellors feel unable to affect athletics. Perhaps it is a product of seeing powerful politicians and deeppocketed alumni rule the roost of athletics at the expense of other parts of the institution. Perhaps it is seeing ineffective governance structures fail in the face of enormous institutional and cultural pressures that favor games on the field instead of rigor in the classroom. Whatever the cause, these faculty see the entire exercise of opposition as a dilemma of opportunity cost: why bother to waste time when it gets nowhere. Time is better spent on those things where directed efforts actually count.

\section{Where Do We Go Now? Moving Outside the System}

The call by many has been for faculty to act not as individuals, but as a collective voice wholly engaged in athletics reform and athletics management. John MacAloon (1991) noted that the problem of intercollegiate athletics "... begins and ends with the tenured faculty. If we do not stand up and insist on this instead of shrugging our shoulders or blaming others, then it is we who are fundamentally dishonest and exploitative" (p. 236). The 2002 AAUP statement, "The Faculty Role in the Reform of Intercollegiate Athletics: Principles and Recommended Practices" lays out specifics for the governance of athletics by the faculty including oversight in the areas of admissions and financial aid, academic standards and support services, and finances. Yet its greatest strength is in its exhortation to the faculty to act with rigor and decisiveness. It proclaims that "faculty must take responsibility at their own institutions for the proper functioning of athletics programs and the appropriate treatment of college athletes as students."

Instead, one might argue that the first step of athletics reform is not in organizing but in engaging. But as I have suggested, it is unclear at this point if faculty members are willing or are able because of historical events and contemporary features. Indeed, more specifically what I have suggested is an inherent systemic problem so deeply 
embedded as to negate any meaningful engagement. What are we to do?

As with others, I offer two possibilities for solution. On the one hand it makes sense to move the athletics enterprise wholly away from anything remotely academic. Just as institutions sometimes provide a wide variety of services - consulting, entertainment, research - that work outside of the traditional channels of academia and in so doing provide a healthy revenue stream to the institution, so too might you finally wash away the disingenuous proclamation of amateurism in college athletics and give to it a proper name: professional and revenue-producing sport. I am not unique in this solution; clearly others have suggested the professional nature of sport and the need to disassociate big-time athletics from the academic soul of a university. Here we might see "players" and "athletes" rather than the misleading "student-athlete" moniker invented so many years ago to keep workman's compensation issues at bay. ${ }^{6}$ Rather, we could perhaps enjoy the success of a university-sponsored team one which still grants revenue and marketing opportunities to the university - without the need for academic interest or faculty engagement. Should faculty still be interested in this endeavor? Perhaps

\footnotetext{
${ }^{6}$ Here one should investigate both the work of Walter Byers (1995) and Staurowsky's and Sack's (2005) more recent "consideration" of student-athlete as an appropriate moniker for participants in intercollegiate athletics.
}

... but only insofar as the resources required or distributed from the endeavor affect the academic program. But clearly the athletics enterprise then would fall to the management of a Chief Financial Officer or some such administrator; we could dispense with the studentdevelopment issues and focus attention on employee management and revenue production.

I would argue that we are lurching towards that very possibility in the next few decades. Conference realignment in Division I athletics seems to be leading us down a path of five or six "superconferences" that will detach themselves from NCAA regulations. That is, these new conference groupings will devise their own rules that focus upon revenue generation and may perhaps address some of the most compelling issues of inequity involving athlete compensation and market value. Let me also suggest that were this to occur, whatever institutions are left standing outside that circle revert back to days of yore and abolish athletics scholarships. The very nature of an athletic scholarship has created a situation where the student is not so much attending the university for educational purposes, but instead is engaged in some kind of indentured servitude where labor creates revenue for those in power. Instead, perhaps we can see students as engaging in pastimes still serious pastimes no doubt as 
meaningful competition should have that characteristic - integrated into the entire developmental experience of students. Without a scholarship there will not exist the symbolic yoke where athletic pursuits must be prioritized above educational aims.

Let me also suggest a second more radical solution, one that certainly could be combined with the first and applied to those schools without scholarships. Others have inclined institutions to allow students to "major" in athletics; the rationale here is that we allow students to study and major in all sorts of performative and professional tracks art, sculpture, dance, welding, and others - and so should we also allow someone to study the performative aspect of sport, particularly through the exercise and practice of that performance. Some might suggest that we have these majors already in place with various sport management and exercise sciences programs. Yet what I am suggesting here is indeed a focus on the performance of the student. Thus one might major in "college athletics" just as one might major in dance or sculpture; certainly a student would need ancillary courses like nutrition and athletic training yet the prime aim of the major would be the creation of outstanding public performance.

Let me extend this argument - and add in the oft-quoted cliché of sport and an "educational experience in itself" and suggest here that entire athletics departments be subsumed under the academic umbrella. Just as there is a department of English or physics that reports to the Provost or Dean of the institution, so, too, might athletics department fall under the watch of the same academic administrator. In this we might see head coaches on the tenure track and assistant coaches as lecturers or instructors. There might still be an athletics director, but this person would act more as the chairperson of a department than the CFO of a fiefdom. Departments would be subject to the standard policies and procedures any other academic department might encounter. Moreover, the highest paid person on campus would not be the head football coach and the second highest his offensive or defensive coordinator. Instead, there might be a salary situation that has logic and sanity dictated by the marketplace of higher education, not the outlandish marketplace of college athletics salaries.

Perhaps most importantly athletics and academics would be forced to engage with one another. We might instead dream there would be no divide because the two camps because they would no longer be in systemic opposition. We do not suggest there is a divide between art and academics or physics and academics because one is in fact a part and representation of the other. Yes, each discipline has its own character and tradition, yet we accept that tradition as 
part of the educational experience of students; there is certainly a "culture" of each discipline but it becomes delightfully encased in an overall academic culture of an institution.

Wishful thinking? Quite so. But the notion of historic and systemic opposition is too deeply enmeshed to provoke meaningful engagement of faculty with contemporary athletics. On the one hand we as faculty could give in and just throw it all out, giving way to the almighty dollar. On the other hand perhaps it is time to truly believe that sport has prosperous educational merit and thus should be taken under our wing. If faculty want to engage and perhaps change the obvious excess in college sports, then it is time to do so on our own turf and in our own actions as the educational heart of an institution; more directly, faculty have an obligation to do so if they are indeed the heart of an institution. Instead of ignoring or complaining, let's open the door and truly have a conversation.

Dr. Travis Feezell currently serves as the Provost and Chief Academic Officer at the University of the Ozarks. In this position Dr. Feezell oversees all aspects of academic and student life at the college. Previously he served as an associate professor and Chair of Sport and Motorsports Management at Belmont Abbey College in Belmont, North Carolina as well as the Special Assistant to the President for Strategic Planning. In addition, he has served previously as an athletics administrator at the Division I level and worked more recently as the athletics director at three different NCAA institutions. 


\section{References}

AAUP Report: The faculty role in the reform of intercollegiate athletics (2002). Academe. Retrieved from http://www.aaup.org/statements/R EPORTS.

Atwell, R. (1991). Sports reform: Where is the faculty? Academe, JanuaryFebruary, 10-12.

Beyer, J. and Hannah, D. (2000). The cultural significance of athletics in U.S. higher education. Journal of Sport Management, 14, 105-132.

Bok, D. (2003). Universities in the marketplace: The commercialization of bigher education. Princeton, NJ: Princeton University Press. Branch, T. (2011). The shame of college sports. The Atlantic, October 2011.

Brown, G. (2007). Faculty group's effort targets integration of athletics. NCAA News, June 4. Retrieved from www.ncaa.org.

Brown, W., Jr. (2001). Faculty participation in university governance and the effects on university performance. Journal of Economic Behavior and Organization, 44, 129-143.

Buer, T. (2009). Organizational complexity: The athletics department and the university. In J.D. Toma and D. Kramer (Eds.), The Uses of Intercollegiate Athletics:

Opportunities and Challenges in Positioning the University (New Directions for Higher Education), 109-116.
Burgan, M. (1998). Academic citizenship: A fading vision. Liberal Education, Fall, 16-21.

Byers, W. (1995). Unsportsmanlike conduct: Exploiting college athletes. Ann Arbor: The University of Michigan Press.

Corrigan, T., Hardin, M., and Nichols, J. (2011). Case studies in athleticacademic integration: A closer look at schools that implement COIA's best practices. Journal of Intercollegiate Sport, 4, 121-146.

Daniel, E. (1992). Faculty governance. Journal of Library Administration, 16(12), 151-166.

DeCock, L. UNC faculty silence has spoken volumes. Charlotte Observer, July 24, 2013. Retrieved from www.charlotteobserver.com.

Drescher, J. UNC faculty: Get in game on NCAA football probe. Charlotte Observer, September 1, 2010. Retrieved from www.charlotteobserver.com.

Duderstadt, James J. (2000). Intercollegiate athletics and the American university: $A$ university president's perspective. Ann Arbor, MI: University of Michigan Press.

Feezell, T. (2005). Faculty attitudes towards intercollegiate athletics at NCAA

Division I and NCAA Division III institutions. Unpublished doctoral dissertation, University of Idaho.

Feezell, T. (2009). Adding football and the "Uses" of athletics at NCAA Division II and Division III institutions. In J.D. Toma and D. 
Kramer (Eds.), The uses of intercollegiate athletics: Opportunities and challenges in positioning the university (New Directions for Higher Education), 148, 65-72.

Feezell, T. (2013). Faculty attitudes towards athletics at NCAA Division II institutions. Journal of Applied Sport Management, 5(2), 72-90.

Flowers, R. (2009). Institutionalized hypocrisy: The myth of intercollegiate athletics. American Educational History Journal, 36(2), 343360.

Frey, J. (1986). The coming demise of intercollegiate athletics. In R. Lapchick (Ed.), Fractured focus: Sport as a reflection of society ( $p$ p. 63-73). Lexington, MA: Lexington Books.

Frey, J. (1985). College athletics:

Problems of institutional control. In D. Chu, J. Seagrave and B. Becker (Eds.), Sport and Higher Education (pp. 179-189).Champaign, IL: Human Kinetics.

Frey, J. (1985). Boosterism, scarce resources, and institutional control: The future of American intercollegiate athletics. In D. Chu, J. Seagrave and B. Becker (Eds.), Sport and Higher Education (pp. 115129).Champaign, IL: Human Kinetics.

Frey, J. (1994). Deviance of organizational subunits: The case of college athletics departments. Journal of Sport and Social Issues, 18(2), 110122.

Gerber, L. (1997). Reaffirming the value of shared governance. Academe, September-October, 14-18.

Gerdy, J. (2006). Air ball: American education's failed experiment with elite athletics. Jackson: University Press of Mississippi.

Hamilton, N. (2000). The academic profession's leadership role in shared governance. Liberal Education, Summer, 12-19.

Knight Commission on Intercollegiate Athletics (2009). Quantitative and qualitative research with football bowl subdivision university presidents on the costs and financing of intercollegiate athletics: Report of findings and implications. Retrieved from http://www.knightcommissionmedi a.org/images/President_Survey_FI NAL.pdf.

Lawrence, J., Ott, M., and Hendricks, L. (2009). Athletics reform and faculty perceptions. In J.D. Toma and D. Kramer (Eds.), The uses of intercollegiate athletics: Opportunities and challenges in positioning the university (New Directions for Higher Education), 148, 73-81.

Lawrence, J., Hendricks, L., and Ott, M. (2007). Faculty survey: Knight Commission national study of faculty perceptions of intercollegiate athletics. Retrieved from 
http://www.knightcommission.org/ images/pdfs/faculty_perceptions_fi nal.pdf.

Lumpkin, A. (2008). A call to action for faculty regarding intercollegiate athletics. Phi Kappa Phi Forum, 88 (1), 21-24.

McPherson, M. (1994). Public purpose and public accountability in liberal education. New Directions for Higher Education, 85, 83-92.

MacAloon, J. (1991). Memory, attention, and the communities of sport. In J. Andre and D. James (Eds.), Rethinking college athletics (pp.223-237). Philadelphia: Temple University Press.

Miller, M., McCormack, T., Maddox, J., and Seagren, A. (1996). Faculty participation in governance at small and large universities: Implications for practice. Planning and Changing, 27(3-4), 180-190.

Nichols, J., Corrigan, T., and Hardin, M. (2011). Integration of athletics and academics: Survey of best practices at FBS schools. Journal of Intercollegiate Sport, 4, 107-120.

Ott, M. (2011). Faculty satisfaction with intercollegiate athletics. Journal of Issues in Intercollegiate Athletics, 4, 370395.

Ridpath, B.D. (2008). Can the faculty reform intercollegiate athletics? A past, present, and future perspective. Journal of Issues in Intercollegiate Atbletics, 1, 11-25.
Ross, K. (1997). The role of faculty in the governance of intercollegiate athletics. Journal of the Indiana University Student Personnel Association, Spring, 65-74.

Sack, A. (2009). Clashing models of commercial sport in higher education: Implications for reform and scholarly research. Journal of Issues in Intercollegiate Athletics, 2, 7692.

Sander, L. (2007). Faculty members discuss what role they should play in athletics. Chronicle of Higher Education, 54 (9), 11.

Scott, Joan. (2002). The critical state of shared governance. Academe.

Retrieved from http:/ /www.aaup.org/publications/ Academe/2002.

Scott, Joanna. (1997). Death by inattention: The strange fate of faculty governance. Academe, November-December, 29-33.

Simon, R. (2008). Does athletics undermine academics? Examining some issues. Journal of Intercollegiate Sport, 1, 40-58.

Smith, R. (1988). Sports and freedom: The rise of big-time college athletics. Oxford: Oxford University Press.

Smith, R. (2011). Pay for play: A bistory of big-time college athletic reform. Urbana: University of Illinois Press. 
Sperber, M. (1990). College Sports, Inc.: The athletics department vs. the university.

New York: Henry Holt.

Sperber, M. (2000). Beer and circus: How

big-time college sports is crippling

undergraduate education. New York:

Henry Holt.

Stancill, J. UNC chancellor says university accepts responsibility for academic fraud. Raleigh News and Observer. January 23, 2014. Retrieved from www.newsobserver.com.

Staurowsky, E. and Sack, A. (2005).

Reconsidering the use of the term student-athlete in academic research. Journal of Sport Management, 19, 103116.

Townsend, R. (2003). Changing relationships, changing values in the American classroom. New Directions for Higher Education, 123, 23-33.

University of North Carolina. (July 26, 2012). Report of the Special Subcommittee (on Athletics) of the Faculty Executive Committee. Chapel Hill, North

Carolina: Steven Bachenheimer, Michael Gerhardt, and Laurie Maffly-Kipp.

Williams, J., Colles, C., and Allen, K. (2010). Division III athletes:

Perceptions of faculty interactions and academic support services. Journal of Issues in Intercollegiate Athletics, 3, 211-233.

Wolverton, B. (2010). Faculty reps botch sports-oversight role. Chronicle of
Higher Education, November 1.

Retrieved from www.chronicle.com.

Wolverton, B. and Fuller, A. (2012).

Who's in charge? Maybe not the president. Chronicle of Higher Education, September 3. Retrieved from www.chronicle.com.

Wolverton, B. (2012). Alleged academic fraud at U. of North Carolina tests NCAA's reach. Chronicle of Higher Education, September 7. Retrieved from www.chronicle.com. 